\title{
INTRODUCTION TO THE ARTICLE BY ELERS KOCH: THE PASSING OF THE LOLO TRAIL
}

\author{
Andrew J. Larson \\ Department of Forest Management, University of Montana, \\ 32 Campus Drive, Missoula, Montana, USA \\ Tel.: +1-406-243-5532; e-mail: a.1arson@umontana.edu
}

\begin{abstract}
In 1935, Elers Koch argued in a Journal of Forestry article that a minimum fire protection model should be implemented in the backcountry areas of national forests in Idaho, USA. As a USDA Forest Service Supervisor and Assistant Regional Forester, Koch had led many major fire-fighting campaigns in the region, beginning with the great 1910 fires of Idaho and Montana. He argued in his classic article for wilderness values, and against throwing millions of dollars into unsuccessful attempts to suppress backcountry fires. His article was accompanied by a response from Earl Loveridge, a proponent of full fire suppression, who was a leader of fire control from the Forest Service Washington Office. Loveridge soon after successfully proposed what was to become known as the 10 AM Policy-a universal fire suppression policy that lasted into the 1970s. While Koch's classic article was not immediately successful in bringing about the backcountry "let burn" fire policy he sought, it did contribute to the designation of the Selway-Bitterroot Primitive Area in 1936, which became a congressionally designated wilderness area in 1964 with the passing of the Wilderness Act. With that, the stage was set for a new era in
\end{abstract}

\section{RESUMEN}

En 1935, Elers Koch argumentó en un artículo publicado en el Journal of Forestry, que un modelo de protección mínima del fuego debería ser implementado en áreas remotas de los Bosques Nacionales de Idaho, EEUU. Como supervisor del Servicio Forestal del Departamento del Agricultura de los EEUU (USDA) y Asistente Forestal Regional, Koch lideró muchas de las mayores campañas de combate de incendios en esta región, comenzando con los grandes incendios de 1910 de Idaho y Montana. Él argumentó en su artículo clásico, sobre el valor de las áreas naturales y en contra de tirar millones de dólares en intentos sin éxito para suprimir incendios en esas áreas remotas. $\mathrm{Su}$ artículo fue acompañado por una respuesta de Earl Loveridge, un proponente de la supresión total del fuego, quien fuera un líder del control de incendios en la oficina del Servicio Forestal en Washington. Loveridge poco después propuso exitosamente lo que se conoció como la política de las 10 AM-una política universal de supresión de fuego que duró hasta los años 1970s. Aunque el artículo clásico de Koch no fue inmediatamente exitoso en promover la política de "dejar quemar" en áreas naturales remotas que él mismo buscaba, éste contribuyó a la creación del área primitiva Sel way Bitterroot en 1936, que se convirtió en un área de reserva natural proclamada por el congreso en 1964 con la aprobación de la Ley de Áreas Naturales (Wilderness Act). Con esta ley, se configuró un nuevo escenario, dando 
Forest Service fire management, and in 1972 the White Cap Creek drainage in the Selway-Bitterroot Wilderness became the first exception to the 10 AM Policy, realizing Koch's vision. comienzo a una nueva era en el manejo del fuego por parte del Servicio Forestal y, en 1972, el drenaje del arroyo White Cap en la Reserva Natural del Selway Bitterroot se convirtió en la primera excepción a la política de las $10 \mathrm{AM}$, plasmándose así la visión de Koch.

Keywords: 10 AM Policy, Bitterroot National Forest, Idaho, Selway-Bitterroot Wilderness, wilderness, wildland fire policy

Citation: Larson, A.J. 2016. Introduction to the article by Elers Koch: The Passing of the Lolo Trail. Fire Ecology 12(1): 1-12. doi: 10.4996/fireecology.1201001

In the February 1935 issue of the Journal of Forestry, Elers Koch, in his then-heretical-now-classic essay The Passing of the Lolo Trail challenged US Forest Service fire suppression doctrine in the backcountry of the Selway and Clearwater drainages in central Idaho. Dismayed by construction of fire protection roads through the wilderness and disillusioned after decades of fruitless attempts to control backcountry conflagrations, Koch questioned the economic rationale and ecological impacts of fire suppression. In his article, he even posits self-regulating fire spread (sensu Parks et al. 2015) and disruption thereof by fire suppression, writing,

It is even possible that, by extinguishing fires in favorable seasons which would have run over a few hundred or a few thousand acres, the stage was only set for the greater conflagrations which went completely beyond fireline control. (Koch 1935)

Elers Koch was the archetypal western professional forester. Born, raised, and educated in Bozeman, Montana, Koch was introduced to forestry through a series of lectures and field trips given by Lt. George P. Ahern at the Montana State College (Koch 1998). Ahern helped Koch secure a summer job with the Bureau of Forestry conducting field research in the Douglas-fir region of western
Washington where, in 1899, he first met the charismatic forester Gifford Pinchot. After that summer, Koch made up his mind to pursue a career in forestry, which at that time meant heading east to Connecticut to study at the new Yale School of Forestry (Koch 1998).

Proud to call himself one of "Gifford Pinchot's young men," Koch joined the Bureau of Forestry after completing a Master of Forestry degree at Yale (Koch 1998). He was assigned to the Boundary Division where he conducted reconnaissance of vast blocks of western forestlands remaining in the public domain, and spent the winter months developing from his notes boundaries for new Forest Reserves proclaimed by President Theodore Roosevelt (Koch 1965). When the Forest Reserves were moved to the Department of Agriculture in 1905, he transitioned to the new role of Inspector, making more tours of western forests, with the focus now on evaluating the politically appointed workforce inherited from the General Land Office (Koch 1965). Late in 1906, Koch received a new assignment: forest supervisor. Koch-one of the few westerners in Pinchot's cadre of young professional foresters-was assigned supervisory responsibility for the Bitterroot, Lolo, and Missoula national forests, headquartered in Missoula, Montana (Koch 1998). Unwilling to return to the Washington Office (Egan 2009), Koch would stay in Missoula for the remainder of his career, advancing to Assistant Regional 
Forester and Chief of Timber Management for Region 1.

Koch was a consummate fire fighter. As they do today, wildfires dominated the activities of Northern Rockies federal foresters in the early twentieth century. Koch got his first lesson in fire fighting in 1908 from the oldtime ranger Frank Hahn (Koch 1965, 1998), then went on to lead major fire-fighting campaigns in 1910, 1919, 1929, and 1934 (Koch 1919, 1935, 1965, 1998; Moore 1996; Egan 2009). Koch was widely recognized for his contributions to fire control efforts, both organizational and technical (Huey 1948). He claimed several fire-fighting innovations, including the Koch tool (a combination shovel-hoe) and an early seen-area map table and alidade fire-finder used in lookout towers (Pyne 1982, Koch 1998). But from 1910 to 1934, he saw defeat after defeat in the face of wildfires, despite the ever increasing technological sophistication and size of the Forest Service fire-fighting organization, and the rapidly expanding network of fire protection roads (Koch 1935). By the end of the 1934 fire season, Koch (1935) wrote,

When fire gets a good start in the dry fire-killed cedar and white fir of the Selway and burning conditions are just right, the whole United States Army, if it was on the ground, could do nothing but keep out of the way.

The full impact of The Passing of the Lolo Trail cannot be understood without considering the state of US Forest Service wilderness preservation and fire-fighting policy in the early 1930s. There was sufficient internal debate about fire suppression policy in the so called "low value" backcountry lands (Pyne 1982, van Wagtendonk 2007) that a special expedition of high-level Forest Service leaders was undertaken in 1932, called the Low Value Lands Expedition, to more fully explore the idea of allowing fires to burn. In an epic twoweek pack trip beginning and ending in Mis- soula, and traversing the full length of the central Idaho wilderness south to Challis, representatives from the Washington Office and several regional foresters, joined by forest supervisors and district rangers responsible for the lands the expedition traversed, debated the merits of full suppression versus more measured fire management tactics in the Idaho backcountry (USFS 1932). Elers Koch was not on this trip, but his immediate supervisor Regional Forester Major Evan Kelley was. The transcripts of the evening discussions revealed that Kelley and some of the Idaho forest supervisors were open to a minimum protection model for the backcountry that included "let burn" and "loose herding" tactics long criticized by California (Region 5) Regional Forester Stuart B. Show (USFS 1932, Pyne 1982). The transcripts also revealed Earl W. Loveridge, Assistant Chief of the Division of Operation and Fire Control, as a major proponent of a unified forest fire suppression policy. As early as September 1932, Loveridge was calling for a full suppression policy on all backcountry fires, exemplified by his first entry in the expedition transcripts (USFS 1932),

\section{I should think that last statement would be a devastating argument against any let burn policy. Has not experience by this time shown us that it is cheaper to put fires out promptly...}

In the fall of 1932, shortly after the conclusion of the Low Value Lands Expedition, Elers Koch corresponded with his good friend, the wilderness advocate Robert "Bob" Marshall (Moore and Baird 2009). In that letter, he argued for setting aside the Selway country as wilderness, making the point that the Selway and Nez Perce backcountry "...was there before the white man came, and in pretty fair shape." Koch further wrote to Marshall that,

I am personally absolutely opposed to any building of roads in primitive areas, even for fire protection purposes... 
I believe the Forest Service has wasted hundreds of thousands of dollars in the back Selway and Nezperce country, and it would have been better if we had long ago set aside these areas to be left without development.

Thus, by fall of 1932, Koch had already formulated his key positions and arguments to eventually be put down in The Passing of the Lolo Trail. Koch went on to draft a memo to the regional forester in October of 1933, encouraging the protection of the Selway backcountry in which he described preliminary boundaries for the primitive area (Moore and Baird 2009).

The 1934 fire season brought Forest Service fire policy to a critical point (Pyne 1982). The crisis Loveridge needed to motivate promulgation of a universal fire suppression policy had arrived in the form of the Pete King and McLendon Butte fires in the Selway and Lochsa country of central Idaho (Swanson 2011). The fires burned for nearly two months, eventually blackening over 100000 ha (250000 acres; Pyne 1982). A distinguished Board of Review was assembled to evaluate the central Idaho fires and make recommendations. Koch's let-burn arguments lost out to Loveridge's "keep every acre green" position on the Board's official report (Pyne 1982).

Koch saw in the Board of Review's recommendations the inevitable degradation of the Selway backcountry that would result from the accelerated road construction required to intensify suppression, and was finally moved to speak out in a public forum. Pyne's (1982) excellent archival research documents the convoluted process leading up to publication of Koch's manuscript. Koch drafted his manuscript quickly after the Board of Review completed its work in the fall of 1934 and, after consulting Kelley and Roy Headley, Chief of the Division of Fire Control, submitted it to the Journal of Forestry. The Journal of Forestry then passed the manuscript to American
Forests, at which point Koch withdrew it from consideration for publication. Koch was worried that his article-being quite critical of Forest Service policy-was too controversial for the popular magazine American Forests. Despite his self-censorship, Koch sent his manuscript as a memo to Chief Forester Ferdinand A. Silcox. While the memo made the rounds at the Washington Office and Loveridge prepared a withering response, Headley encouraged Koch to again send the manuscript to the Journal of Forestry; Koch acquiesced. The manuscript was published in the February 1935 issue (Koch 1935), accompanied by a condescending rebuttal from Loveridge (1935) and an equally disdainful editorial preface.

Loveridge's ultimate response to Koch's heretical essay, however, did not arrive until later in the spring of 1935. Loveridge could not match Koch's prose, but he could outmaneuver him within the hierarchal ranks of Forest Service administration. At the regional foresters conference in April 1935, Loveridge answered Koch even more forcefully by proposing what was to become known as the $10 \mathrm{AM}$ Policy (Pyne 1982). With Show's lobbying, Loveridge's proposed policy was unanimously approved by the assembled brass (Pyne 1982), and formalized as Forest Service policy on 7 May 1935, in a letter from Chief Silcox to agency staff (Loveridge 1943). Loveridge finally got what he so earnestly wanted - a universal fire suppression policy that applied even to low value backcountry lands. Loveridge had championed his cause for years (USFS 1932), but it was Koch's eloquent article that finally created the opportunity Loveridge needed to bring about the 10 AM Policy.

Koch's plea for a rational backcountry fire management policy may have backfired, but his lament over the incursion of fire protection roads into the great central Idaho wilderness ultimately produced results. While Koch could not overcome Loveridge and his allies, his friend Bob Marshall had direct access to, and considerable influence on, Chief Forester 
Silcox (Glover 1986, Moore and Baird 2009). At Koch's urging, Marshall had been working to protect the Selway wilderness from road building and development since late 1932 (Moore and Baird 2009). Marshall elevated the Selway wilderness as his top priority for protection in a 16 May 1935 memo to Silcox, just days after issuance of the 10 AM Policy. In a 26 November 1935 meeting of several regional foresters, senior Washington Office staff, and Chief Forester Silcox, Bob Marshall finally secured agreement to protect the Selway backcountry (Moore and Baird 2009). The formal designation of the Selway-Bitterroot Primitive Area under Regulation L-20 was signed on 3 July 1936 (Swanson 2015). Elers Koch drew the boundaries (Slusher 1958, Moore and Baird 2009).

Two threads of influence emanate from Koch's essay: Loveridge's reactionary 10 AM Policy and Marshall's successful campaign to designate the Selway-Bitterroot Primitive Area. These threads diverged in Forest Service policy and practice for a time, but they began to converge in 1964 with the passing of the Wilderness Act and congressional designation of the Selway-Bitterroot Wilderness. The Wilderness Act gave new direction and authority to manage for natural processes in wilderness areas. By 1969, wilderness managers recognized fire suppression as trammeling an essential natural process, setting the stage for a new era in Forest Service fire management (van Wagtendonk 2007). The seminal White Cap Creek wilderness fire management study (Aldrich and Mutch 1972) brought the two threads of Koch's essay together again when Chief John McGuire approved, on 17 August 1972, the White Cap Creek drainage in the Selway-Bitterroot Wilderness as the first ever exception to the 10 AM Policy.

\section{ACKNOWLEDGEMENTS}

I thank C. Miller for sharing historical documents and for her enthusiastic support. B. Mutch generously shared unpublished manuscripts, as well as the history of the White Cap Creek study. I thank O. Daniels for sharing his thoughts on Koch's stature in the USFS and the influence of his essay. The Selway-Bitterroot Wilderness History Project of the University of Idaho Library is an exceptional archive of historical documents, upon which I drew heavily. A. Cansler provided a constructive review of an earlier draft.

\section{LITERATURE CITED}

Aldrich, D.F., and R. W. Mutch. 1972. Ecological interpretations of the White Cap drainage: a basis for wilderness fire management. USDA Forest Service, Missoula Fire Sciences Laboratory, Missoula, Montana, USA.

Egan, T. 2009. The big burn. Houghton Mifflin Harcourt, New York, New York, USA.

Glover, J.M. 1986. A wilderness original: the life of Bob Marshall. The Mountaineers, Seattle, Washington, USA.

Huey, B.M. 1949. Elers Koch: 40-year federal forester. Journal of Forestry 47: 113-114.

Koch, E. 1919. Selway fire report. USDA Forest Service Northern Region archives. <http:// sbw.lib.uidaho.edu/Pages/11.pdf>. Accessed 5 February 2016.

Koch, E. 1935. The passing of the Lolo Trail. Journal of Forestry 33: 98-104.

Koch, E. 1965. Launching of the USFS in the Northern Region. Forest History Newsletter 9(3): 9-13.

Koch, E. 1998. Forty years a forester. Mountain Press, Missoula, Montana, USA. 
Loveridge, E.W. 1935. The opposite point of view. Journal of Forestry 33: 105-110.

Loveridge, E.W. 1944. The fire suppression policy of the US Forest Service. Journal of Forestry 42: 549-554.

Moore, B. 1996. The Lochsa story: land ethics in the Bitterroot Mountains. Mountain Press, Missoula, Montana, USA.

Moore, A.M., and D. Baird. 2009. Wild places preserved: the story of Bob Marshall in Idaho. University of Idaho Library, Moscow, Idaho, USA.

Parks, S.A., L.M. Holsinger, C. Miller, and C.R. Nelson. 2015. Wildland fire as a self-regulating mechanism: the role of previous burns and weather in limiting fire progression. Ecological Applications 25: 1478-1492. doi: 10.1890/14-1430.1

Pyne, S.J. 1982. Fire in America: a cultural history of wildland and rural fire. Princeton University Press, Princeton, New Jersey, USA.

Slusher, E. 1958. Notes from study of files. Moose Creek Ranger District, historical files. University of Idaho Library. <http://sbw.lib.uidaho.edu/Pages/80.pdf $>$. Accessed 5 February 2016.

Swanson, F.H. 2011. The Bitterroot and Mr. Brandborg: clearcutting and the struggle for sustainable forestry in the Northern Rockies. The University of Utah Press, Salt Lake City, Utah, USA.

Swanson, F.H. 2015. Where roads will never reach: wilderness and its visionaries in the Northern Rockies. The University of Utah Press, Salt Lake City, Utah, USA.

USFS [US Forest Service]. 1932. A record from discussions held during the Low Value Area Expedition. University of Idaho Library. <http://sbw.lib.uidaho.edu/Pages/29.pdf $>$. Accessed 5 February 2016.

van Wagtendonk, J.W. 2007. The history and evolution of wildland fire use. Fire Ecology 3(2): 3-17. doi: 10.4996/fireecology.0302003 